\title{
Sterols compositions, antibacterial, and antifouling properties from two Malaysian seaweeds: Dictyota dichotoma and Sargassum granuliferum
}

\author{
Kamariah Bakar ${ }^{1}$, Habsah Mohamad ${ }^{1 *}$, Hock Seng Tan², Jalifah Latip ${ }^{3}$ \\ ${ }^{1}$ Institute of Marine Biotechnology, Universiti Malaysia Terengganu, Terengganu, Malaysia. \\ ${ }^{2}$ Institute of Oceanography and Environment, Universiti Malaysia Terengganu, Kuala Nerus, Terengganu, Malaysia. \\ ${ }^{3}$ School of Chemical Sciences and Food Technology, Faculty of Science and Technology, Universiti Kebangsaan Malaysia, Selangor, Malaysia.
}

\begin{tabular}{l}
\hline ARTICLE INFO \\
\hline Received on: 01/12/2018 \\
Accepted on: 09/07/2019 \\
Available online: 05/10/2019
\end{tabular}

Key words:

Dictyota dichotoma,

Sargassum granuliferum, antibacterial, antifouling, sterol, seaweeds.

\begin{abstract}
Seaweeds or macroalgae are the primary producers of an oceanic food source, widely distributed across the globe and known for their excellent defensive properties against numerous biotic and abiotic factors. These defensive traits come from their secondary metabolites that act as protective barriers against pathogens and harmful organisms where among these compounds some have been found possessing the antifouling characteristic. In this study, Dictyota dichotoma and Sargassum granuliferum collected from Pulau Nunuyan Laut, Sabah, Malaysia, were studied to determine its sterol composition, and isolation was carried out to isolate their pure sterol compounds. Two assays consist of disk diffusion method for antibacterial activity and crystal violet assay were carried out to study its antifouling activity. Campesterol, stigmasterol, and $\beta$-sitosterol were the dominant sterol compound detected in both samples and six pure sterols were isolated (compounds 1-6). Results from the antibacterial and antifouling analysis showed better inhibition for Gramnegative compared to Gram-positive bacteria. Fucosterol (4) and epicoprostanol (5) gave the best antibacterial activity with two bacteria inhibited compared to other compound. Meanwhile, coprostanol (1), campesterol (2), stigmasterol (3), epicoprostanol (5), and 5 $\beta$-cholestan-3-one (6) showed strong antifouling activity towards the selected bacterial strains with $\mathrm{IC}_{50}$ values ranges from 266.3 to $425.8 \mu \mathrm{g} / \mathrm{ml}$.
\end{abstract}

\section{INTRODUCTION}

The extensive coastline with rocky shores and sandy bays, as well as numerous coral fringe islands found along the coastlines of Peninsular Malaysia, Sarawak, and Sabah, provides niche habitat for a variety of seaweed species in Malaysia water. In recent years, the use of natural antifouling based materials has been greatly explored and studies have been reporting on their capability against antifouling activities (Almeida and Vasconcelos, 2015; Guanther et al., 2007; Qian et al., 2015).

\footnotetext{
"Corresponding Author

Habsah Mohamad, Institute of Marine Biotechnology,

Universiti Malaysia Terengganu, Terengganu, Malaysia.

E-mail: habsah@umt.edu.my
}

Present technologies in inhibiting settlement and growth of marine fouling organisms mostly rely on antifouling paint formulated with inorganic compounds, such as Irgarol 1051, tributyl-tin (TBT), and other brands that are available in the market (Fisher et al., 1999; Grinwis et al., 1998). The most effective component in antifouling paints is TBT which is detrimental and not degraded in the natural ecosystem (Soliman et al., 2017). These inorganic chemicals action mode of either being toxic or sub-lethal and have been proved affecting the marine ecosystem (Bhadury and Wright, 2004; Soliman et al., 2017). In addition to that, the effects of biofouling also give the implication to the aquaculture industries where they implicate the cultured organisms for space and food deteriorating farming infrastructure as well as affecting the natural habitat on neighboring areas (Gopikrishnan et al., 2015). Thus, it is important in developing a green antifoulant alternative for 
combatting foulants at the same time safe to the environments. (De Nys and Steinberg, 2002; Fusetani, 2004; Guenther and De Nys, 2007). The green antifoulant may consist of isolated compounds from natural resources such as marine organism (Clare, 1996). Researchers studying on ascidians, bryozoans, cnidarians, and seaweeds had proven that these marine organisms are potentially for antimicrobial, antifungal, and antilarval activities (Clare, 1996; Fusetani, 2004; Qian et al., 2012;). Seaweed is a marine macroalga and they are rich sources of secondary metabolites (Bhadury and Wright, 2004) of which these metabolites functioned as antibacterial, antifungal, antiprotozoan, antiherbivores, antiepibiosis, or antifouling and so on (Clare, 1996; Da Gama et al., 2002; Hellio et al., 2001; Pawlik, 1992). Dictyota dichotoma and Sargassum granuliferum are abundantly distributed at Pulau Nunuyan Laut, Sabah, Malaysia. To the best of our knowledge, there is still no report on sterol composition for these seaweeds. Thus, we initiate this study to determine their sterol composition as well as the ability in antibacterial and antifouling.

\section{MATERIALS AND METHODS}

\section{Seaweeds collection and preparation}

Fresh $D$. dichotoma and $S$. granuliferum were collected via scuba diving (6-9 m) at Pulau Nunuyan Laut, Sabah, Malaysia $\left(05^{\circ} 56.030^{\prime} \mathrm{N} ; 118^{\circ} 06.609^{\prime} \mathrm{E}\right)$ on June 2009 Voucher specimens (MARC08P0054, MARC08P0073) were deposited at Institute of Oceanography and Environment (INOS), Universiti Malaysia Terengganu. Collected seaweeds were cleaned from debris and airdried. Dried samples of $D$. dichotoma and $S$. granuliferum were cut into small pieces and ground into powder using a metal grinder.

\section{Extraction and isolation of sterols from S. granuliferum and D. dichotoma}

Dried powder of $D$. dichotoma $(2 \mathrm{~kg})$ and $S$. granuliferum $(2.3 \mathrm{~kg})$ was soaked separately with $2.5 \mathrm{~L}$ of methanol and shake using orbital shaker at the speed of $120 \mathrm{rpm}$ for a period of 3 days. Soaked samples were then filtered to remove solid particles from the solvent extracts. These procedures were repeated thrice and the collected extracts were evaporated using a rotary evaporator. Samples were then partitioned with petroleum ether, chloroform, ethyl acetate, and butanol, with a similar process as mentioned above. Isolation and characterization of pure compounds from the extracts of $D$. dichotoma and $S$. granuliferum were done using column chromatography and preparative thin-layer chromatography techniques. Table 1 shows the different solvent extracts for D. Dichotoma and S. granuliferum. Butanol extract of D. dichotoma (DDB) was not tested in this study due to the low yield of crude extract.

Table 1. Different solvent extracts for D. dichotoma and S. granuliferum.

\begin{tabular}{lcc}
\hline \multirow{2}{*}{ Types of solvent } & \multicolumn{2}{c}{ Seaweed samples } \\
\cline { 2 - 3 } & D. dichotoma & S. granuliferum \\
\hline Methanol & DDM & SGM \\
Petroleum ether & DDP & SGP \\
Chloroform & DDC & SGC \\
Ethyl acetate & DDE & SGE \\
Butanol & DDB & SGB \\
\hline
\end{tabular}

\section{Sterol analysis}

Sterols were fractionated from each crude extracts using liquid-solid chromatography technique with silica and alumina as its stationary phase. $5 \alpha$-androstanol was spiked into the crudes and sterol compounds were eluted using Dichloromethane: $\mathrm{MeOH}$ $(1: 9 \mathrm{v} / \mathrm{v})$. The sterol fractions collected were then pre-concentrated using rotary evaporator to a volume of approximately $3 \mathrm{~mL}$ and the final volume were adjusted to $1 \mathrm{ml}$ using nitrogen blowdown. Sterol compounds were silylated using N,O-Bis(trimethylsilyl) trifluoroacetamide-trimethylchlorosilane (99:1) and identification was carried out using a Shimadzu QP2010 GCMS equipped with $5 \%$ phenyl methyl siloxane (DB-5) column with helium as the carrier gas. The oven temperature was programmed at $70^{\circ} \mathrm{C}(2$ minutes) ramp to $180^{\circ} \mathrm{C}\left(4^{\circ} \mathrm{C} /\right.$ minute $)$, increase to $300^{\circ} \mathrm{C}\left(5^{\circ} \mathrm{C} /\right.$ minute) and isothermal for 15 minutes. Injector and detector temperatures were maintained at $300^{\circ} \mathrm{C}$. Sterol compounds detected were identified and verified using major mass ion $\left(\mathrm{M}^{+}\right)$, retention times compared to those of external sterol standards (e.g., campesterol, cholesterol, $\beta$-sitosterol, stigmasterol) and/ or mass spectra from published literature (Hayee-Memon et al., 1991; Kaloustian et al., 2008; Kala et al., 2015; Rohloff, 2015) and GCMS library (NIST 2014 and WILEY 229).

\section{Antibacterial assay}

Antibacterial activity of pure sterols isolated was tested using paper disk diffusion technique against five bacteria, namely, Vibrio alginolyticus, Vibrio parahaemolyticus, Vibrio mimicus, Pseudomonas aeruginosa, and Bacillus subtilis, which were obtained from Microbiology Laboratory of Institute of Marine Biotechnology, Universiti Malaysia Terengganu. Gentamycin and Penicillin-G $(10 \mu \mathrm{g})$, while Chloramphenicol $(30 \mu \mathrm{g})$ were used as positive controls while all pure sterol tested were $1 \mathrm{mg} /$ $\mathrm{ml}$. All bacteria were cultured in appropriate broths at $30^{\circ} \mathrm{C}$ for overnight and concentration were matched to the density of a 0.5 McFarland standard. Agar cultures and bacterial test were prepared as described by Razmavar et al. (2014). All determination was carried out in triplicates.

\section{Anti-fouling assay}

The crystal violet biofilm assay method was performed on the pre-sterilized 96-well flat-bottom polystyrene microtiter plates in triplicate as mentioned by Stepnovic et al. (2000) with some modifications. In this assay, $V$. alginolyticus, $V$. mimicus, $V$. parahaemolyticus, $P$. aeruginosa, and $B$. subtilis were chosen for their ability to form a biofilm. Different compounds isolated from $D$. dichotoma and $S$. granuliferum were added at the specified concentrations. Negative control well was also included for bacterial culture without compounds addition. Briefly, $20 \mu \mathrm{l}$ of bacteria suspension having $0.5 \mathrm{OD}_{595}$ was inoculated in $230 \mu \mathrm{l}$ Luria Bertani broth on a microtiter plate and incubated at $37^{\circ} \mathrm{C}$ for 24 hours period. Once incubated, the microtiter plate was washed twice with sterile water and $200 \mu \mathrm{l}$ of absolute methanol was added and allowed to contact for 15 minutes. Crystal violet in water solution $(1 \% \mathrm{v} / \mathrm{v})$ was added to the plate and then removed and washed with distilled water and dried. Finally, 33\% (v/v) glacial acetic acid was added and agitated in ELISA for 15 minutes. The agitated solution was then transferred to a new sterile 96-well 
plate. Optical density (OD) was measured using ELISA reader at $595 \mathrm{~nm}$ and the percentage of bacteria inhibition concentration was calculated as follows:

$$
\begin{aligned}
\% \text { Inhibition concentration }= & {[(\text { OD growth control }- \text { OD sample })} \\
& / \text { OD growth control }] \times 100
\end{aligned}
$$

\section{RESULTS AND DISCUSSION}

Pure sterol compounds isolated from D. dichotoma and S. granuliferum

In this section, six pure sterol compounds were obtained from the isolation of the partition extracts from $D$. dichotoma and $S$. granuliferum. Isolation and purification of the main compounds were carried out on silica gel and Sephadex LH20 column chromatography to obtain six pure compounds. Structural elucidation of these compounds was based on the data obtained from ${ }^{1} \mathrm{H}-\mathrm{NMR}$ and ${ }^{13} \mathrm{C}-\mathrm{NMR}$ studies. Separated compounds from $S$. granuliferum and $D$. dichotoma were identified as coprostanol (1), campesterol (2), stigmasterol (3), fucosterol (4), epicoprostanol (5), and 5 $\beta$-cholestan-3-one (6) compared to the spectral data reported in the literature (Fig. 1). ${ }^{13} \mathrm{C}-\mathrm{NMR}$ data of sterols isolated from S. granuliferum and D. dichotoma are summarized in Table 2.

\section{Sterol composition in D. dichotoma and S. granuliferum}

Results of overall sterol compounds identified in the crude extracts of $D$. dichotoma and $S$. granuliferum using GCMS are presented in Table 3. Table 4 shows the percentage of sterol compounds detected in different crude extracts of $D$. dichotoma and $S$. granuliferum. S. granuliferum sample exhibited more sterol with 13 compounds compared to $D$. dichotoma which detected 11 compounds. In $D$. dichotoma sample, 24-nor-22, 23-methylenecholest-5-en-3 $\beta$ ol, 25-hydroxy-24-methylcholesterol, and saringosterol were not detected in all extracts while $S$. granuliferum sample did not exhibit the presence of fucosterol in all the extracts. It was observed that both $D$. dichotoma and $S$. granuliferum samples were mainly dominated by campesterol, stigmasterol, and $\beta$-sitosterol. These phytosterols are found abundant in plant and they function in maintaining the structure and physiology of cell membranes. They function by the limiting movement of fatty acyl chains which decrease membrane permeability and regulate its fluidity (Piironen et al., 2000), and Schuler et al. 1991 found sitosterol to be effective in limiting water permeability in the soybean. Previous studies on brown algal reported that fucosterol [stigmasta-5, (E)-24(28)-dien-3ß-ol] (Easa et al., 1995; Newburger et al., 1979; Smith et al., 1973) and saringosterol [24-ethylcholesta-5, 28-diene-313, 24-diol] (Amico et al., 1980; Ikekawa et al., 1968) were the dominant compound found. In this study, fucosterol was found in all $D$. dichotoma crude extracts but not as dominant sterol while saringosterol was only found in methanol, petroleum ether, and ethyl acetate crude extract of $S$. granuliferum sample. The absence of fucosterol in the studied sample extracts is due to degradation into saringosterol epimers where fucosterol is highly reactive and easily oxidize to saringosterol (Bouzidi et al., 2014), whereas the absence of saringosterol in D. dichotoma extracts was due to that saringosterol peak in the respective samples exhibits weak molecular mass fragmentation in the GCMS total ion chromatogram; thus, difficult for conformation with NIST 2014 and WILEY 229 library and is not reported in this study. Furthermore,
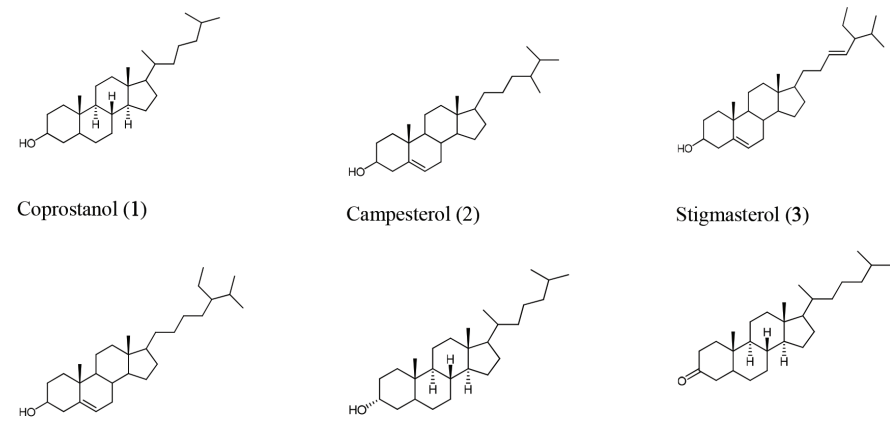

Campesterol (2)

Stigmasterol (3)

Fucosterol (4)
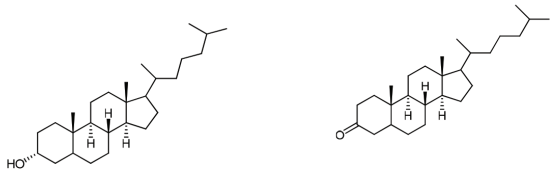

Figure 1. Chemical structures of isolated sterols from $S$. granuliferum and $D$. dichotoma.

\begin{tabular}{|c|c|c|c|c|c|c|}
\hline $\begin{array}{l}\text { Carbon } \\
\text { number }\end{array}$ & 1 & 2 & 3 & 4 & 5 & 6 \\
\hline 1 & 35.5 & 36.5 & 37.3 & 37.3 & 35.4 & 37.2 \\
\hline 2 & 31.6 & 31.7 & 31.7 & 31.7 & 30.6 & 37.1 \\
\hline 3 & 71.4 & 71.8 & 71.8 & 71.8 & 71.9 & 213.5 \\
\hline 4 & 38.3 & 42.3 & 42.3 & 42.3 & 36.2 & 42.4 \\
\hline 5 & 40.1 & 140.8 & 140.8 & 140.8 & 42.2 & 40.9 \\
\hline 6 & 28.8 & 121.7 & 121.7 & 121.7 & 28.3 & 26.7 \\
\hline 7 & 32.1 & 33.9 & 31.9 & 31.9 & 26.5 & 28.3 \\
\hline 8 & 35.8 & 36.1 & 31.9 & 31.9 & 35.8 & 35.6 \\
\hline 9 & 54.4 & 50.2 & 50.2 & 50.1 & 40.5 & 44.4 \\
\hline 10 & 35.5 & 37.3 & 36.5 & 36.5 & 34.6 & 34.9 \\
\hline 11 & 21.3 & 26.3 & 21.1 & 21.1 & 20.9 & 21.2 \\
\hline 12 & 42.6 & 39.8 & 39.7 & 39.8 & 40.2 & 39.5 \\
\hline 13 & 44.9 & 42.3 & 42.2 & 42.4 & 42.7 & 42.7 \\
\hline 14 & 56.5 & 56.8 & 56.9 & 56.8 & 56.6 & 56.5 \\
\hline 15 & 23.8 & 24.3 & 24.4 & 24.3 & 24.3 & 25.8 \\
\hline 16 & 28.2 & 29.2 & 28.9 & 55.8 & 27.2 & 24.2 \\
\hline 17 & 56.3 & 56.1 & 55.9 & 11.9 & 56.4 & 56.4 \\
\hline 18 & 12.1 & 11.9 & 12.1 & 19.4 & 12.0 & 18.7 \\
\hline 19 & 12.3 & 19.8 & 18.9 & 36.4 & 22.6 & 12.1 \\
\hline 20 & 36.2 & 33.9 & 40.5 & 18.8 & 36.5 & 37.8 \\
\hline 21 & 18.7 & 21.2 & 21.2 & 35.2 & 18.7 & 22.7 \\
\hline 22 & 37.0 & 45.9 & 138.3 & 25.7 & 35.9 & 36.2 \\
\hline 23 & 24.2 & 26.1 & 129.3 & 147.0 & 23.9 & 23.8 \\
\hline 24 & 28.0 & 19.3 & 51.2 & 34.8 & 39.5 & 40.1 \\
\hline 25 & 39.5 & 29.7 & 31.9 & 22.2 & 28.0 & 28.0 \\
\hline 26 & 22.8 & 21.1 & 21.2 & 22.1 & 22.8 & 22.6 \\
\hline 27 & 22.6 & 18.8 & 19.4 & 115.6 & 23.4 & 22.8 \\
\hline 28 & & 11.8 & 25.4 & 13.2 & & \\
\hline
\end{tabular}

Table 2. ${ }^{13} \mathrm{C}$ NMR $\left(125 \mathrm{MHz}, \mathrm{CDCl}_{3} \mathrm{dc}\right)$ chemical shifts of compounds.

the high concentration of campesterol, stigmasterol and $\beta$-sitosterol and fucosterol in this study was similar to Kanias et al. (1992) who studied Padina pavonia from the Aegean Sea. The studied area Pulau Nunuyan, Sabah, is located in the Sulu Sea having a warm tropical climate with an average seawater temperature of $28^{\circ} \mathrm{C}$. This warmer temperature might be the reason for higher campesterol, stigmasterol, and $\beta$-sitosterol compared to fucosterol. The differences in sterol 
Table 3. GCMS data of sterols from D. dichotoma and S. granuliferum.

\begin{tabular}{lcc}
\hline Compound name & Experimental major mass Ion $\left(\mathbf{M}^{+}\right)$ & GCMS major mass ion $\left(\mathbf{M}^{+}\right)$ \\
\hline Coprostanol & $370,355,257,215$ & $370,355,257,215$ \\
Epicoprostanol & $370,355,257,215$ & $370,355,257,215$ \\
24-Nor-22,23-methylenecholest-5-en-3ß-ol & $456,366,3255,129$ & \\
Cholesterol & $386,368,328,129$ & $386,368,329,129$ \\
Cholestanol & $388,373,215$ & $388,373,355,215$ \\
24-Methyl-22-dehydrocholesterol & $470,380,215,129$ & \\
25-Hydroxy-24-methylcholesterol & $470,386,256,129$ & \\
Brassicasterol & $470,380,255,129$ & $470,380,255,129$ \\
Campesterol & $472,382,255,129$ & $472,382,255,129$ \\
Stigmasterol & $484,394,255,129$ & $484,394,255,129$ \\
Fucosterol & $412,314,281,129$ & $412,314,281,129$ \\
$\beta$-Sitosterol & $486,396,357,129$ & $486,396,357,129$ \\
Saringosterol & $416,396,357$ & $416,396,357$ \\
\hline
\end{tabular}

Table 4. Sterol compound detected in different crude extracts of D. dichotoma and S. granuliferum.

\begin{tabular}{|c|c|c|c|c|c|c|c|c|c|}
\hline \multirow{3}{*}{ Compound Name } & \multicolumn{9}{|c|}{ Percentage of sterol in different solvent partition crude extract } \\
\hline & \multicolumn{4}{|c|}{ Dictyota dichotama } & \multicolumn{5}{|c|}{ S. granuliferum } \\
\hline & DDM & DDP & DDC & DDE & SGM & SGP & SGC & SGE & SGB \\
\hline Coprostanol & 0.19 & - & 0.38 & 0.12 & 0.02 & 0.02 & - & 0.03 & 0.01 \\
\hline Epicoprostanol & 0.50 & - & - & - & 0.21 & 0.17 & 7.60 & - & - \\
\hline 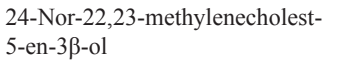 & - & - & - & - & 1.78 & 3.92 & - & 5.17 & 16.6 \\
\hline Cholesterol & 9.60 & - & - & 1.20 & 5.51 & 6.72 & - & 13.2 & 11.8 \\
\hline Cholestanol & 28.8 & 1.91 & 5.40 & - & 0.51 & 1.13 & - & 1.79 & - \\
\hline 24-Methyl-22-dehydrocholesterol & 5.23 & 8.79 & 6.31 & 5.84 & 5.16 & 7.29 & - & 6.39 & 20.1 \\
\hline $\begin{array}{l}\text { 25-Hydroxy-24- } \\
\text { methylcholesterol }\end{array}$ & - & - & - & - & 3.10 & - & - & 8.40 & 16.7 \\
\hline Brassicasterol & 3.61 & 8.04 & 4.33 & 4.87 & 5.04 & 7.15 & - & 5.43 & 20.1 \\
\hline Campesterol & 18.2 & 30.5 & 20.4 & 17.7 & 14.7 & 29.6 & - & 3.99 & 8.32 \\
\hline Stigmasterol & 25.1 & 22.3 & 30.9 & 8.07 & 32.8 & 32.0 & 31.9 & 4.10 & 6.39 \\
\hline Fucosterol & 3.37 & 24.3 & 6.81 & 30.0 & - & - & - & - & - \\
\hline$\beta$-Sitosterol & 5.32 & 4.18 & 25.4 & 32.2 & 29.2 & 5.60 & 60.5 & 34.9 & - \\
\hline Saringosterol & - & - & - & - & 2.03 & 6.49 & - & 16.6 & - \\
\hline
\end{tabular}

SGM $=$ Methanol extract of $S$. granuliferum, $\mathrm{SGP}=$ Petroleum etherl extract of $S$. granuliferum, $\mathrm{SGC}=$ Chloroform extract of $S$. granuliferum, $\mathrm{SGE}=\mathrm{Ethyl}$ acetate extract of $S$. granuliferum, $\mathrm{SGB}=$ Buthanol extract of $S$. granuliferum, DDM = Methanol extract of Dictytota dichotoma, $\mathrm{DDP}=\mathrm{Petroleum}$ ether extract of Dictytota dichotoma, $\mathrm{DDC}=$ Chloroform extract of Dictytota dichotoma, $\mathrm{DDE}=$ Ethyl acetate extract of Dictytota dichotoma,- Not detected

composition and its abundances could be due to differences in the life cycle of the algae and their ecological conditions (Ikekawa et al., 1968; Kanias et al., 1992; Kamernarska et al., 2002; 2003;

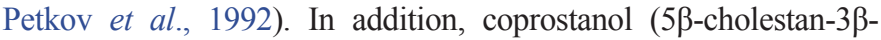

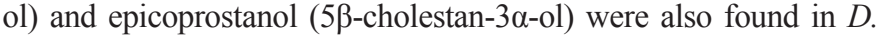
dichotoma and $S$. granuliferum crude extract. It is interesting to note that these two compounds were normally associated with sewage discharge; thus, the presence of them in the sample studied should be further studied to ascertain their origin.

\section{Antibacterial activity}

Antibacterial activities of all pure sterol compounds were tested against adhesive Gram-positive bacteria (B. subtilis) and Gram-negative bacteria ( $V$. alginolyticus, $V$. parahaemolyticus, $V$. mimicus, and $P$. aeruginosa). In this study, the bacteria selected were mostly from the Gram-negative strains due to Gram-negative bacteria with different characteristics were the major strain in the marine environment and accounted for $90 \%$ of marine bacteria population (Iyyapparaj et al., 2012). The high density of this bacteria is due to their cell wall is highly adapted for the high salinity environment (Das et al., 2006). Results of antibacterial activities obtained for all pure sterol compounds tested were shown in Table 5. In general, all pure sterol compounds of both seaweeds showed better inhibition against Gram-negative bacteria compared to Gram-positive bacteria. Compound $\mathbf{5}$ gave the best inhibition with two Gram-positive bacteria inhibited while other compounds only inhibited one Gram-positive bacteria. The zones of growth inhibition for Gram-negative bacteria were almost similar for all compounds with inhibition range of 7.2-9.6 $\mathrm{mm}$. Meanwhile, compound $\mathbf{4}$ is the only compound that gave 
Table 5. Antibacterial activity of sterol pure compounds against (a) V. alginolyticus (b) V. mimicus (c) Vibrio parahaemolyticus (d) P. aeruginosa (e) B. subtilis

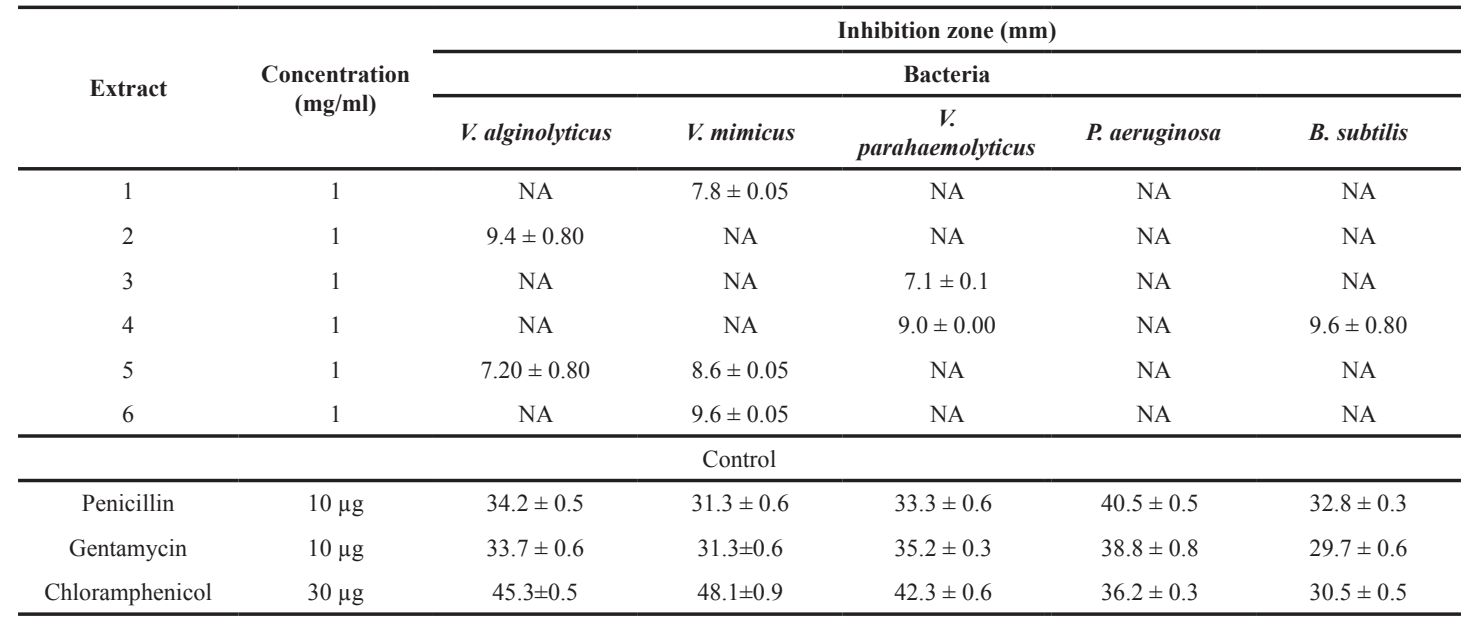

Table 6. Crystal violet biofilm activity of sterol pure compounds against (a) V. alginolyticus (b) V. mimicus (c) Vibrio parahaemolyticus (d) P. aeruginosa (e) B. subtilis.

\begin{tabular}{|c|c|c|c|c|c|}
\hline \multirow{3}{*}{ Sample } & \multicolumn{5}{|c|}{$\mathrm{IC}_{50}(\mu \mathrm{g} / \mathrm{ml})$} \\
\hline & \multicolumn{5}{|c|}{ Bacteria } \\
\hline & V. alginolyticus & V. mimicus & V. parahaemolyticus & P. aeruginosa & B. subtilis \\
\hline 2 & $425.79 \pm 0.14$ & NA & NA & NA & NA \\
\hline 3 & NA & NA & $560.07 \pm 0.07$ & NA & NA \\
\hline 5 & $269.00 \pm 0.06$ & $314.81 \pm 0.07$ & NA & NA & NA \\
\hline 6 & NA & $143.60 \pm 0.04$ & NA & NA & NA \\
\hline
\end{tabular}

$\mathrm{NA}=$ no activity.

inhibition for Gram-positive bacteria. The greater inhibition for Gram-negative compared to Gram-positive bacteria obtained for all sterol compounds was in opposite trend compared to other research studies on antimicrobial activities from seaweeds (Dussault et al., 2016; Kavita et al., 2014). The abundances of Gram-negative bacteria in the marine environment is well-known; therefore, results of antibacterial activity obtained in this study bring new insight for the development of antimicrobials against Gram-negative bacteria from seaweed-based natural products.

\section{Anti-fouling activity}

All pure sterol compounds isolated from $D$. dichotoma and $S$. granuliferum were tested for antifouling activity using crystal violet assay. Coprostanol (1), campesterol (2), stigmasterol (3), epicoprostanol (5), and 5 $\beta$-cholestan-3-one (6) showed strong inhibition towards the selected bacterial strains with $\mathrm{IC}_{50}$ values ranges from 266.3 to $425.8 \mu \mathrm{g} / \mathrm{mL}$, while fucosterol (4) gave no activity for all bacterial strain tested (Table 6). Results obtained showed these compounds gave better inhibition properties for Gram-negative bacteria compared to Gram-positive bacteria. Epicoprostanol (5) is the most active compounds which inhibit two types of bacteria $V$. alginolyticus $(269.00 \pm 0.06)$ and $V$. mimicus $(314.81 \pm 0.07)$. Microtiter plate system for quantifying biofilm formation has been investigated using many different organisms and strains (Christensen et al., 1985; Deighton and Balkau, 1990;
Miyake et al., 1992; Ramage et al., 2001; Stepanović et al., 2000). Crystal violet staining method is a good technique in measuring the amount of biofilm formed but not on its activity. Thus, this technique is suitable for quantifying biofilm removal but not disinfection (Pitts et al., 2003).

Therefore, the results of this study present the possibility of sterol compound to be used as a potential natural antifouling substance.

\section{CONCLUSION}

Results from this study showed sterol compounds isolated from $D$. dichotama and $S$. granuliferum exhibit antibacterial and antifouling activities on Gram-negative bacteria compared to Gram-positive bacteria. This characteristic is important because Gram-negative bacteria are the dominant bacteria present in the marine ecosystem and they play an important part in bio-film processing. Therefore, the sterol compounds of these seaweeds can be utilized for developing a promising green antifouling alternative in combating marine water biofilm.

\section{CONFLICTS OF INTEREST}

The authors declare that they have no conflicts of interest.

\section{FINANCIAL SUPPORT AND SPONSORSHIP}

None. 


\section{REFERENCES}

Almeida JR, Vasconcelas V. Natural antifouling compounds: Effectiveness in preventing invertebrate settlement and adhesion. Biotechnol Adv, 2015; 33:343-57.

Amico V, Oriente G, Piattelli M, Tringali C, Fattorusso E, Magno S, Mayol L. Diterpenes based on the dolabellane skeleton from Dictyota dichotoma. Tetrahedron, 1980; 36:1409-14.

Bhadury P, Wright PC. Exploitation of marine algae: biogenic compounds for potential antifouling applications. Planta, 2004; 219:561-78.

Bouzidi N, Yannick V, Annick O-M, Halima S, Zahia A, Yasmina

D, Gerald C, Mohamed E-H. Sterols from the brown alga Cystosiera Foeniculacea : degradation of fucosterol into saringosterol epimers. Arab J Chem, 2014; 2014:1-5.

Christensen GD, Simpson WA, Younger JJ, Baddour LM, Barret FF, Melton DM, Beachey EH. Adherence of coagulase-negative staphylococci to plastic tissue culture plates: a quantitative model for the adherence of staphylococci to medical devices. J Clin Microbiol, 1985; 22:996-1006.

Clare AS. Marine natural product antifoulants: status and potential. Biofouling, 1996; 9:211-29.

Da Gama BAP, Pereira RC, Carvalho AGV, Coutinho R, Yoneshigue YV. The effects of seaweed secondary metabolites on biofouling. Biofouling, 2002; 18:13-20.

Das S, Lyla PS, Khan SA. Marine microbial diversity and ecology: Importance and future perspectives. Curr Sci, 2006; 90:1325-35.

Deighton MA, Balkau B. Adherence measured by microtiter assay as a virulence marker for Staphylococcus epidermis infection. J Clin Microbiol, 1990; 28(11):2442-7.

De Nys R, Steinberg PD. Linking marine biology and biotechnology. Curr Opin Biotechnol, 2002; 13:244-8.

Dussault $\mathrm{D}$, Vu KD, Vansach $\mathrm{T}$, Horgen FD, Lacroix M. Antimicrobial effects of marine algal extracts and cyanobacterial pure compounds against five foodborne pathogens. Food Chem, 2016; 199: $114-8$.

Easa HS, Kornprobst JM, Rizk AM. Major sterol composition of some algae from Quatar. Phytochemistry, 1995; 39(2):373-4.

Fisher WS, Oliver LM, Walker WW, Manning CS, Lytle TF. Decreased resistence of eastern oysters (Crassostrea virginica) to a protozoan pathogen (Perkinsus marinus) after sublethal exposure to tributyltin oxide. Mar Environ Res, 1999; 47:185-201. 21:94-104

Fusetani N. Biofouling and antifouling. Nat Prod Rep, 2004;

Gopikrishnan V, Radhakrishnan M, Pazhanimurugan R, Shanmugasundram T, Balagurunathan R. Natural products: Potential and less explored source for antifouling compounds. J Chem Pharm Res, 2015; 7(7):1144-53

Grinwis GCM, Boonstra A, Brandhof EJ, Dormans JAMA, Engelsma M, Kuiper RV, Loveren HV, Wester PW, Vaal MA, Vethaak AD, Vos JG. Short-term toxicity of bis(tri-n-butyltin)oxide in flounder (Platichthys flesus): pathalogy and immune function. Aquat Toxicol, 1998; 42:15-36.

Guenther J, De Nys R. Surface microtopographies of tropical sea stars; lack of an efficient physical defence mechanis against fouling. Biofouling, 2007; 23(6): 419-29.

Guenther J, Walker-Smith G, Waren A, de Nys R. Foulingresistant surfaces of tropical sea stars. Biofouling, 2007; 23:413-8.

Hayee-Memon A, Shameel M, Ahmad M, Ahmad VU, Usmanghani K. Phycochemical studies on Gracilaria foliifera (Gigartinales, Rhodophyta). Bot Mar, 1991; 34:107-11.

Hellio C, Broise DDL, Dufossé L, Gal YL, Bourgougnon $\mathrm{N}$. Inhibition of marine bacteria by extracts of macroalgae: potential for environmentally friendly antifouling paints. Mar Environ Res, 2001; 52(3):231-47.
Ikekawa N, Morisaki N, Tsuda K, Yoshida, T. Sterol compositions in some green algae and brown algae. Steroids, 1968; 12:41-8.

Iyapparaj P, Ramasubburayan R, Raman T, Das N, Kumar P, Palavesam A, Immanuel G. Evidence for the antifouling potentials of marine macroalgae Sargassum wightii. Adv Nat Appl Sci, 2012; 6(2):153-62.

Kala KJ, Prashob PKJ, Chandramohanakumar N. Cytotoxic potential of fucosterol isolated from Turbinaria Conoides against Dalton's lymphoma ascites. Int J Pharmacogn Phytochem Res, 2015; 7(6):1217-21.

Kaloustian J, Alhanout K, Amiot-Carlin MJ, Lairon D, Portugal H, Nicolay A, Technical C. Effect of water cooking on free phytosterol levels in bean and vegetables. Food Chem, 2008; 107:1379-86.

Kamenarska ZG, Yalçin FN, Ersöz T, Çaliş I, Stefanov K, Popov S. Chemical Composition of Cystoseira crinita Bory from the Eastern Mediterranean. Z. Naturforsch, 2002; 57c:584-90.

Kamenarska ZG, Dimitrova-Konaklieva SD, Stefanov KL, Popov SS. A comparative study on the sterol of some brown algae from the Black Sea. J Serb Chem Soc, 2003; 68(4-5):269-75.

Kanias GD, Skaltsa H, Tsitsa E, Loukis A, Bitis J. Study of the correlation between trace elements, sterols and fatty acids in brown algae from the Saronikos Gulf of Greece. Fresenius J Anal Chem, 1992; 344: $334-9$.

Kavita K, Singh VK, Jha B. 24-Branched 5 sterol from Laurencia papillosa red seaweed with antibacterial activity against human pathogen bacteria. Microbiol Res, 2014; 169:301-6.

Miyake Y, Fujiwara S, Usui T, Suginaka H. Simple method for measuring the antibiotic concentration required to kill adherent bacteria. Chemotherapy, 1992; 38:286-90.

Newburger, JD, Uebel JJ, Ikawa M, Andersen KK, Gagosian RB Sterols of Agarum cribosum: Demonsterol in a brown alga. Phytochemistry, 1979; 18:2042-3.

Pawlik, JR. Chemical ecology of the settlement of benthic marine invertebrates. Oceanogr Mar Biol, 1992; 30:273-335.

Petkov GD, Furnadzieva ST, Popov SS. Petrol-induced changes in the lipid and sterol composition of three microalgae. Phytochem, 1992; 31(4):1165-6.

Piironen V, Lindsay DG, Miettinen TA, Toivo J, Lampi AM Plant sterols: biosynthesis, biological function, and importance to human nutrition. J Sci Food Agric, 2000; 80:939-66.

Pitts B, Hamilton MA, Zelver N, Stewart PS. A microtiterplate screening method for biofilm disinfection and removal. J Microbiol Methods, 2013; 54(2):269-76.

Qian PY, Li Z, Xu Y, Li Y, Fusetani N. Mini-review: Marine natural products and their synthetic analogs as antifouling compounds: 2009-2014. Biofouling, 2015; 31(1):101-22.

Qian PY, Xu Y, Fustani N. Natural products as antifouling compounds: recent progress and future perspectives. Biofouling, 2012; 26(20):223-34.

Ramage G, Vande-Walle K, Wickes BL, López-Ribot JL. Standardized method for in vitro antifungal susceptibility testing of Candida albicans biofilms. Antimicrob Agents Chemother, 2001; 45:2475-9.

Razmavar S, Abdulla MA, Ismail SB, Hassandarvish P. Antibacterial activity of leaf extracts of Baeckea fructescens against methicillin-resistant Staphylococcus aureus. Biomed Res Int, 2014; 2014:1-5.

Rohloff J. Analysis of phenolic and cyclic compounds in plants using derivatisation techniques in combination with GC-MS based metabolite profiling. Molecules, 2015; 20:3431-62.

Schuler I, Milon A, Nakatani Y, Ourisson G, Albrecht AM, Benveniste P, Hartmann MA. Differential effects of plant sterols on water permeability and on acyl chain ordering of soybean phosphatidylcholine bilayers. Proc Natl Acad Sci USA, 1991; 88:6926-30. 
Smith LI, Dhart AK, Gilchrist Jl, Lin YY. Sterols of the brown alga Sargassum fluitans. Phytochemistry, 1973; 12:2727-32.

Soliman YAA, Brahim AM, Moustafa AH, HAmed MAF. Antifouling evaluation of extracts from Red Sea soft corals against primary biofilm and biofouling. Asian Pac J Trop Biomed, 2017; 7(11):991-7.

Stepanović S, Vukovic D, Dakic I, Savic B, Svabic-Vlahovic M. A modified microtiter-plate test for quantification of staphylococcal biofilm formation. J Microbiol Methods, 2000; 40:175-9.
How to cite this article:

Bakar K, Mohamad H, Tan HS, Latip J. Sterols compositions, antibacterial, and antifouling properties from two Malaysian seaweeds: Dictyota dichotoma and Sargassum granuliferum. J Appl Pharm Sci, 2019; 9(10):047-053. 